\title{
Effect of L-arginine on amniotic fluid index in oligohydramnios
}

\section{Rinoy Sreedharan*, Shubhada Jajoo}

\begin{abstract}
Department of Obstetrics \& Gynecology, Jawaharlal Nehru Medical College, AVBRH, Sawangi, Meghe, Wardha,
\end{abstract} Maharashtra-442002, India

Received: 15 January 2013

Accepted: 19 January 2013

*Correspondence:

Dr. Rinoy Sreedharan

E-mail: rinoys@gmail.com

\begin{abstract}
Background: Oligohydramnios is a common diagnosis in obstetrics and carries an increased risk of operative interference and perinatal mortality and morbidity. Identification and proper management of oligohydramnios can result in a favourable outcome. The administration of L-arginine (nitric oxide donor) has been suggested to improve the amniotic fluid index (AFI) in oligohydramnios.

Methods: This is a prospective study conducted over a period of two years. A total of 100 women attending antenatal clinic of Acharya Vinoba Bhave Rural Hospital, Sawangi (Meghe), Wardha who were diagnosed with oligohydramnios were included. Women who fulfilled the inclusion criteria were prescribed sachets of L-arginine containing $3 \mathrm{~g}$ of the active ingredient for periods varying between 1 to 4 weeks. Change in AFI was noted.

Results: L-arginine increases the amniotic fluid index in cases of oligohydramnios by $2.03 \pm 0.39 \mathrm{~cm}$.

Conclusions: L-arginine could be a potent treatment option for treatment of oligohydramnios. However extensive long-term studies are required to demonstrate not only its efficacy but also effect on maternal and perinatal outcome.
\end{abstract}

Keywords: Oligohydramnios, L-arginine, Amniotic fluid index

\section{INTRODUCTION}

Oligohydramnios is a condition in which the amniotic fluid is decreased. It was quantified as an amniotic fluid index (AFI) less than $5 \mathrm{~cm}^{1}$ However, now a more commonly used definition of oligohydramnios is amniotic fluid index less than the 5th percentile for the gestational age. $^{2}$

Oligohydramnios is associated with an adverse perinatal and maternal outcome. Ultrasound guided amnioinfusion is an option for treatment commonly being employed nowadays. Since it is an invasive procedure there is an inherent risk of fetal loss. Another modality employed since a long period of time is maternal hydration though results have been varied and there is no standard treatment protocol for the same. A recently propagated alternative for the treatment of oligohydramnios is the administration of L-arginine which has been found to be effective in cases of intrauterine growth restriction and
Pregnancy Induced Hypertension. ${ }^{3}$ However there is no literature as of yet studying the effect of L-arginine on amniotic fluid index.

This study was conducted to see the effect of L-arginine administration on AFI in patients with oligohydramnios.

\section{METHODS}

The study was a prospective study conducted in Department of Obstetrics and Gynaecology at Acharya Vinoba Bhave Rural Hospital, Sawangi (Meghe), Wardha over a period of two years extending from September 2009 to September 2011. A total of 100 women attending antenatal clinic of Acharya Vinoba Bhave Rural Hospital, Sawangi (Meghe), Wardha who were diagnosed with oligohydramnios were included following consent and fulfilment of criteria. Follow up of the patients was done and findings analysed. 
The ethical approval was taken from the Institutional Ethics Committee (IEC).

Selection Criteria: Patient giving consent for the study, gestational age between 28-36 weeks, Amniotic Fluid Index lesser than 5th percentile for the particular gestational age in the latest sonography. ${ }^{2}$

Exclusion Criteria: Patient not giving consent for the study, diagnosed major congenital anomalies, history of having received treatment for oligohydramnios.

Methods: Women who fulfilled the inclusion criteria were prescribed sachets of L-arginine containing $3 \mathrm{~g}$ of the active ingredient for periods varying between 1 to 4 weeks. Repeat scan was done on follow up and the AFI noted. Change in AFI was noted.

\section{RESULTS}

The mean age of women in the study was $24.15 \pm 3.38$ years. The mean gestational age at diagnosis of oligohydramnios was $31.1 \pm 2$ weeks (Table 1 ).

Table 1: Distribution of women according to gestational age (weeks) at diagnosis.

\begin{tabular}{|c|c|c|c|}
\hline $\begin{array}{l}\text { Gestational } \\
\text { age (weeks) }\end{array}$ & $\begin{array}{l}\text { No. of } \\
\text { Women } \\
(n=100)\end{array}$ & $\begin{array}{l}\text { Mean } \\
\text { gestational } \\
\text { age }\end{array}$ & $\begin{array}{l}\text { Standard } \\
\text { Deviation }\end{array}$ \\
\hline $\begin{array}{l}28-30 \\
30.1-32 \\
32.1-34 \\
34.1-36\end{array}$ & $\begin{array}{l}30(30 \%) \\
38(38 \%) \\
26(26 \%) \\
6(6 \%)\end{array}$ & 31.1 & 2 \\
\hline
\end{tabular}

Women received treatment for 1-4 weeks with an average duration of treatment of 23.99 \pm 3.51 days (Table 2). The average change in AFI was $2.03 \pm 0.39 \mathrm{~cm}$ (Table 3).

Table 2: Distribution of women according to duration of treatment with respect to gestational age at diagnosis.

\begin{tabular}{|c|c|c|c|}
\hline \multirow{2}{*}{$\begin{array}{l}\text { GA at } \\
\text { diagnosis } \\
\text { (weeks) }\end{array}$} & \multicolumn{3}{|c|}{ Duration of treatment (days) } \\
\hline & 8-14 days & $\begin{array}{l}15-21 \\
\text { days }\end{array}$ & $\begin{array}{l}22-28 \\
\text { days }\end{array}$ \\
\hline $28-30(n=30)$ & $1(3 \%)$ & $9(30 \%)$ & $20(67 \%)$ \\
\hline $30.1-32(n=38)$ & $0(0 \%)$ & $12(32 \%)$ & $26(68 \%)$ \\
\hline $32.1-34(n=26)$ & $1(4 \%)$ & $10(38 \%)$ & $15(58 \%)$ \\
\hline $34.1-36(n=6)$ & $3(50 \%)$ & $3(50 \%)$ & $0(0 \%)$ \\
\hline Mean & \multicolumn{3}{|l|}{23.99} \\
\hline SD & \multicolumn{3}{|l|}{3.51} \\
\hline
\end{tabular}

Table 3: Average change in AFI.

\begin{tabular}{|c|c|c|c|}
\hline $\begin{array}{l}\text { GA at } \\
\text { diagnosis } \\
\text { ( } n=\text { number } \\
\text { of women) }\end{array}$ & $\begin{array}{l}\text { Avg. } \\
\text { Change in } \\
\text { AFI }(\mathrm{cm}) \\
\text { after } \\
\text { treatment } \\
\text { for 8-14 } \\
\text { days }\end{array}$ & $\begin{array}{l}\text { Avg. } \\
\text { Change in } \\
\text { AFI }(\mathbf{c m}) \\
\text { after } \\
\text { treatment } \\
\text { for } 15-21 \\
\text { days }\end{array}$ & $\begin{array}{l}\text { Avg. } \\
\text { Change in } \\
\text { AFI } \\
\text { (cm)after } \\
\text { treatment } \\
\text { for 22-28 } \\
\text { days }\end{array}$ \\
\hline $28-30(n=30)$ & 2.2 & 1.75 & 2.1 \\
\hline $30.1-32(n=38)$ & - & 1.8 & 2.26 \\
\hline $32.1-34(n=26)$ & 1.7 & 1.8 & 2.3 \\
\hline $34.1-36(n=6)$ & 1.6 & 2 & 0 \\
\hline $\begin{array}{l}\text { Average } \\
\text { change in AFI }\end{array}$ & 2.03 & & \\
\hline SD & 0.39 & & \\
\hline
\end{tabular}

\section{DISCUSSION}

With the easier availability of ultrasonography nowadays more cases of oligohydramnios are being identified. This helps us to be more cautious and anticipate problems especially during labour. However the need for an effective, economical, easily available treatment modality remains unmet. Maternal dehydration has been always believed to cause oligohydramnios though it cannot be coined as the cause in every case. Recently, serial ultrasound guided amnioinfusions have been tried but with varying success rates. Moreover it carries the inherent danger of fetal loss as it is an invasive procedure. L-arginine is a versatile amino acid with a wide range of biological functions. It serves as a precursor not only to proteins but also nitric oxide which has been identified as endothelium-derived relaxing factor. ${ }^{4}$ L-arginine increases uteroplacental blood flow through nitric oxide mediated dilatation of vessels thereby increasing the supply of nutrients to the fetus aiding its growth. In a study by Ropacka et al, L-arginine was found to be effective in cases of Intrauterine growth restriction. ${ }^{3}$ Similarly in another study in growth restricted and pre-eclamptic patients by Dera et al, use of L-arginine was associated with lower rate of operative deliveries and higher Apgar scores at both 1 and 5 minutes. ${ }^{5}$

In our study the mean age of women was $24.15 \pm 3.38$ years with a range from 19 years to 35 years. The average gestational age of the women included in the study was $31.1 \pm 2$ weeks.

In our study the mean duration of treatment was a $23.99 \pm 3.51$ days which was lesser than in a similar study by Ropacka et al in which duration of therapy in study 
group was $34.1 \pm 13.8$ days. ${ }^{3}$ This could be due to patients being less compliant with the treatment in our country.

The mean change in AFI in women in our study was $2.03 \mathrm{~cm} \pm 0.39 \mathrm{~cm}$. This is a positive effect and it suggests that L-arginine could be useful in cases far from term with oligohydramnios.

In our country where facilities for treatment options like amnioinfusion are not easily available, L-arginine could be used as an effective method of treatment. It has the added advantage of being non-invasive and not requiring hospitalization.

\section{CONCLUSIONS}

The present study points towards the effectiveness of Larginine in increasing amniotic fluid index in cases of oligohydramnios. However extensive long-term studies are required to demonstrate not only its efficacy but also its effect on maternal and perinatal outcome which would help in establishing its role as a potent treatment option for oligohydramnios.

Funding: No funding sources

Competing interests: There are no competing interests to declare
Ethical approval: The study was approved by the institutional ethical committee

\section{REFERENCES}

1. Mercer LJ, Brown LG, Petres RE, et al. A survey of pregnancies complicated by decreased amniotic fluid. Am J Obstet Gynecol 1984;149:355-61.

2. Moore TR, Cayle JE. The amniotic fluid index in normal human pregnancy. Am J Obstet Gynecol 1990;162:1168-73.

3. Ropacka M, Kowalska J, Blumska-Hepner K, Markwitz W, Bręborowicz GH. Effect of L-arginine on fetal outcome in IUGR fetuses. Arch Perinat Med 2007;13:30-4

4. Palmer RM, Ashton DS, Moncada S. Vascular endothelial cells synthesize nitric oxide from Larginine. Nature 1988;333:664-6.

5. Dera A, Ropacka M, Kowalska J, Markwitz W, Nycz $\mathrm{P}$, Bręborowicz GH. The effect of L-arginine treatment on the neonatal outcome from pregnancies complicated by intrauterine growth restriction and gestational hypertension. Arch Perinat Med 2007;13:35-9.

DOI: $10.5455 / 2320-1770 . i j r \operatorname{cog} 20130214$

Cite this article as: Sreedharan R, Jajoo S. Effect of L-arginine on amniotic fluid index in oligohydramnios. Int J Reprod Contracept Obstet Gynecol 2013;2:80-2. 